As-Syifaa Jurnal Farmasi Desember 2020;12(2):123-130.

ISSN : 2502-9444 (electronic); 2085-4714 (printed)

Journal Homepage : http://jurnal.farmasi.umi.ac.id/index.php/as-syifaa

\title{
EVALUASI PENGGUNAAN ANTIBIOTIK PADA PASIEN INFEKSI SALURAN PERNAFASAN DI PUSKESMAS RAWAT JALAN KECAMATAN SIULAK MUKAI KABUPATEN KERINCI TAHUN 2018
}

\author{
Rasmala Dewi, Deny Sutrisno, Andral Pramirta \\ Program Studi Farmasi, STIKES Harapan Ibu Jambi \\ Email: a pramirta@yahoo.com
}

\begin{abstract}
Respiratory infections a major health problem that is commonly found in Indonesia. The height prevalence of respiratory tract infections and their effects have consequences high consumption of over the counter medicines and antibiotics. This research aims to evaluating the use of antibiotics which includes the right patient, the right indication of the drug, the right dose, and the interaction of the drug in patients with respiratory infections in outpatien health centers in the district of Siulak Mukai in Kerinci District in 2018. This study is a observational research is descriptive in nature by collecting data on records medical outpatients retrospectively according to age inclusion criteria 25 years, patients with a diagnosis of respiratory tract infections in outpatient health centers in the district of Siulak Mukai, Kerinci Regency in 2018, complete medical record data and analyzed with the guidelines of Pharmaceutucal Care 2005 with descriptive methods. The results of evaluating the use of antibiotics in patients with respiratory tract infections in outpatient clinics in the district of Siulak Mukai in Kerinci Regency in 2018, showed that $100 \%$ apporopriate treaments, as well as the incidence of antibiotic drug interactions by 2 events.
\end{abstract}

Key words: Respiratory Tract Infections, Evaluation Of Antibiotic Use, Siulak Mukai Health Center.

\section{PENDAHULUAN}

Indonesia merupakan wilayah yang sering terjadinya kebakaran hutan dan lahan, terutama di pulau Sumatera. Dampak dari kebakaran hutan menjadi suatu bentuk bencana alam yang mempunyai dampak terhadap aspek-aspek kehidupan masyarakat. Seperti kejadian bencana asap yang diakibatkan kebakaran hutan sudah beberapa kali terjadi di Indonesia. Gangguan asap tersebut juga berdampak negatif terhadap kesehatan masyarakat seperti menculnya gangguan Infeksi Saluran Pernafasan. ${ }^{1}$ Infeksi saluran pernafasan merupakan masalah kesehatan utama yang banyak ditemukan di Indonesia. Tingginya prevalensi penyakit infeksi saluran pernafasan serta dampak yang ditimbulkan membawa akibat pada tingginya konsumsi obat bebas dan antibiotik. ${ }^{1}$
Provinsi Jambi termasuk wilayah yang sering terjadi kebakaran hutan di Indonesia. ${ }^{2}$ Kebakaran di Provinsi Jambi yang penyebaran asapnya sangat luas di daerah-daerah yang berada di sekitarnya. Tingginya tingkat pencemaran udara menyebabkan masalah penyakit Infeksi Saluran Pernafasan memiliki angka yang paling banyak diderita oleh masyarakat dibandingkan penyakit lainya yaitu sekitar 20,55\%. ${ }^{1}$ Dari hasil Riskesdas 2018 prevalensi ISPA berdasarkan diagnosis Nakes turun dari 13,8\% di tahun 2013 menjadi 4,4\% di tahun $2018 .^{3}$

Kabupaten Kerinci merupakan salah satu yang terkena dampak dari kebakaran hutan, adanya aktivitas sekelompok masyarakat di dalam kawasan hutan, adapun tujuannya untuk membersihkan lahan untuk pertanian, perladangan dan sebagainya. 
Puskesmas Rawat Jalan Kecamatan Siulak Mukai merupakan Puskesmas yang terletak di desa Mukai Mudik Kecamatan Siulak Mukai Kabupaten Kerinci.

Berdasarkan data dari Dinas Kesehatan Kabupaten Kerinci penyakit (ISPA) menduduki urutan pertama dari 10 penyakit terbesar terhitung dari Januari-Desember 2018 $\begin{array}{llll}\text { tercatat sebanyak } & 15.449 & \text { Pasien. }\end{array}$ Berdasarkan survey awal yang dilakukan di Puskesmas Siulak Mukai Kabupaten Kerinci, Jumlah pasien ISPA ditahun 2018 mencapai 1.317 pasien.

Antibiotik merupakan salah satu pilihan untuk mengatasi Infeksi Saluran Pernafasan. Antibiotik digunakan untuk mengatasi infeksi yang disebabkan oleh bakteri sehingga penggunaannya harus tepat untuk menghindari terjadinya resistensi mikroorganisme terhadap antibiotik. Menurut $\mathrm{WHO}$, terdapat beberapa kriteria untuk dapat dikatakan bahwa suatu pemberian obat sudah tepat yaitu harus memenuhi persyaratan $4 \mathrm{~T}$ yaitu tepat pasien, tepat indikasi, tepat obat, dan tepat dosis serta mewaspadai efek samping obat yang mungkin terjadi. Pemilihan dan penggunaan antibiotik yang tepat akan menentukan keberhasilan pengobatan. $^{5}$

Selain itu tidak menutup kemungkinan penggunaan obat dapat menimbulkan Drug Related Problems (DRP), Maka Farmasis harus dapat mendeteksi, mengatasi dan mencegah masalah yang terjadi atau yang akan terjadi dalam penggunaan antibiotik.

\section{METODE PENELITIAN}

Penelitian ini merupakan penelitian observasional bersifat deskriptif dengan pengambilan data secara rerospektif. Data yang diambil yaitu data rekam medik pasien dan data buku registrasi poliklinik pasien yang didiagnosis infeksi saluran pernafasan di Puskesmas Rawat Jalan Kecamatan Siulak Mukai Kabupaten Kerinci pada tahun 2018.

Data yang diperoleh dalam penelitian ini dikelompokkan berdasarkan katagori masing-masing. Kemudian data dianalisis dan dipersentasekan dalam bentuk tabel untuk mengetahui jumlah pasien berdasarkan usia, jenis kelamin, jenis obat antibiotik yang digunakan. Analisis evaluasi ketepatan obat antibiotik meliputi tepat pasien, tepat indikasi, tepat dosis, dan interaksi obat.

\section{HASIL DAN PEMBAHASAN}

\section{Analisis Data Kuantitatif}

Tabel 1. Persentase Pasien Infeksi Saluran Pernafasan Berdasarkan Usia

\begin{tabular}{|c|c|c|c|}
\hline No. & Usia (Tahun) & Jumlah Pasien & Persentase (\%) \\
\hline 1 & $26-35$ & 21 & 22.34 \\
\hline 2 & $36-45$ & 18 & 19.14 \\
\hline 3 & $46-55$ & 19 & 20.21 \\
\hline 4 & $56-65$ & 14 & 14.89 \\
\hline 5 & $>65$ & 22 & 23.40 \\
\hline \multicolumn{2}{|r|}{ Total } & 94 & 100 \\
\hline
\end{tabular}

* Keterangan: Rentang Usia Berdasarkan Kementrian Kesehatan Republik Indonesia tahun 2009.

Umur atau usia adalah satuan waktu yang keberadaan suatu benda atau makhluk, baik yang hidup maupun yang mati. Semisalnya, umur manusia dikatakan lima belas tahun diukur sejak dia lahir hingga waktu umur itu dihitung. Oleh yang demikian umur diukur dari terakhir lahir sehingga terakhir masanya. Pada penelitian ini kategori usia dibagi berdasarkan Departemen Kesehatan Republik Indonesia tahun 2009 yaitu masa 
dewasa awal usia 26-35 tahun, masa dewasa akhir usia 36-45 tahun, masa lansia awal usia 46-55 tahun, masa lansia akhir usia 56-65 tahun, dan masa manula usia $>65$ tahun. ${ }^{6}$

Berdasarkan hasil penelitian yang telah dilakukan di Puskesmas Kecamatan Siulak Mukai Kabupaten Kerinci tahun 2018 didapatkan jumlah sampel sebanyak 94 pasien dari data rekam medik dan data buku registrasi poli umum didapatkan pasien Infeksi Saluran Pernafasan yang terbanyak pada rentang usia > 65 tahun, dengan persentase 23,40 \% dengan jumlah 22 pasien, hal ini karena daya tahan dan kemampuan tubuh melawan serangan bakteri pada umur tua dibandingkan dengan orang dewasa yang lebih mud. ${ }^{7}$

Hal ini tidak berbeda dengan hasil penelitian sebelumnya yang dilakukan di Instalasi Rawat Jalan Rumah Sakit Umum Pusat H.Adam Malik Medan yang menyebutkan bahwa ISPA lebih banyak pada pasien dengan usia $>65$ tahun sebesar $58 \%$ dengan jumlah sebanyak 40 pasien. ${ }^{8}$ Biasanya lanjut usia lebih signifikan dan lebih cepat terkena bakteri maupun virus yang menyebabkan infeksi saluran pernafasan. Dalam hal ini lanjut usia lebih rentan terkena berbagai macam penyakit. ${ }^{9}$

Tabel 2. Persentase Jenis Kelamin Pasien Infeksi Saluran Pernafasan

\begin{tabular}{cccc}
\hline No. & Jenis Kelamin & Jumlah Pasien & Persentase (\%) \\
\hline 1 & Laki-laki & 35 & 37.23 \\
2 & Perempuan & 59 & 62.76 \\
\hline & Total & $\mathbf{9 4}$ & $\mathbf{1 0 0}$ \\
\hline
\end{tabular}

Berdasarkan hasil penelitian yang telah dilakukan di Puskesmas Rawat Jalan Kecamatan Siulak Mukai Kabupaten Kerinci tahun 2018 didapat jumlah sampel sebanyak 94 pasien dilihat bahwa jumlah pasien dengan jenis kelamin perempuan lebih banyak mengalami Infeksi Saluran Pernafasan dibandingkan jenis kelamin laki-laki, dimana pasien perempuan dengan jumlah 59 pasien, dengan persentase $62,76 \%$, dan pasien laki-

Tabel 3. Persentase Jenis Antibiotik Yang Digunakan

\begin{tabular}{cccc}
\hline No. & Jenis Antibiotik & Jumlah Pasien & Persentase (\%) \\
\hline 1 & Amoksisilin & 58 & 61.70 \\
2 & Ciprofloksasin & 19 & 20.21 \\
3 & Cefixime & 13 & 13.82 \\
4 & Kotrimokazol & 4 & 04.25 \\
\hline & Total & $\mathbf{9 4}$ & $\mathbf{1 0 0}$ \\
\hline
\end{tabular}

Dari hasil penelitian ini golongan antibiotik yang paling banyak digunakan pada pasien Infeksi Saluran Pernafasan di Puskesmas Rawat Jalan Kecamatan Siulak Mukai Kabupaten Kerinci Tahun 2018 adalah laki dengan jumlah 35 pasien, dengan persentase $37,23 \%$. Hubungan antara jenis kelamin tidak berpengaruh terhadap kejadian Infeksi Saluran Pernafasan, semua memiliki resiko yang sama antara laki-laki dan perempuan, karena secara umum penyebab Infeksi Saluran Pernafasan adalah berbagai organisme, namun yang terbanyak akibat infeksi virus dan bakteri. ${ }^{10}$ 
ciprofloksasin (15,38\%), dan golongan

sulfonamida yaitu kotrimoxazol $(04,25 \%)$.

Pada penelitian ini jenis antibiotik amoksisilin lebih menjadi pilihan untuk terapi penyakit Infeksi Saluran Pernafasan karena kelebihan amoksisilin yaitu biaya rendah, aman, efektif, dan antibiotik spektrum luas. ${ }^{11}$
Amoksisilin yang merupakan turunan dari penisilin merupakan antibiotik yang bersifat broad spectrum sehingga merupakan pilihan antibiotik yang relatif aman dan sesuai untuk pengobatan Infeksi Saluran Pernafasan. Antibiotik ini merupakan antibiotik lini pertama untuk pasien Infeksi Saluran Pernafasan. ${ }^{10}$

Tabel 4. Persentase (\%) Tepat Pasien Terhadap Obat Antibiotik Yang Digunakan

\begin{tabular}{ccc}
\hline Tepat Pasien & Jumlah Pasien & Persentase (\%) \\
\hline Tepat & 94 & 100 \\
Tidak Tepat & 0 & 0 \\
\hline Total & $\mathbf{9 4}$ & $\mathbf{1 0 0}$
\end{tabular}

Tepat pasien yaitu antibiotik yang diberikan sesuai dengan kondisi fisiologis dan patofisiologis pasien untuk menghindari adanya kontraindikasi yang mungkin terjadi yang dapat memperburuk atau memperparah kondisi pasien. Kriteria tepat pasien dilihat dari ada atau tidak adanya reaksi hipersensitifitas (alergi) terhadap antibiotik dan riwayat penyakit sebelumnya yang di alami pasien yang memiliki kontraindikasi terhadap antibiotik. Apabila pasien memiliki alergi dan riwayat penyakit sebelumnya memiliki kontraindikasi terhadap antibiotik yang diberikan maka dinyatakan tidak tepat pasien. ${ }^{11}$
Pada penelitian ini antibiotik yang deberikan adalah amoksisilin, ciprofloksasin, cefixime, kotrimoxazol sudah memenuhi kriteria tepat pasien. Berdasarkan data rekam medik dan data buku registrasi pasien poli umum, tidak dituliskan atau dicantumkan bahwasanya pesien memiliki riwayat alergi dan riwayat penyakit sebelumnya terhadap antibiotik yang digunakan, sehingga menunjukan tidak ada pemberian antibiotik yang kontraindikasi terhadap kondisi pasien yang dapat memperparah atau memperburuk keadaan pasien, maka hasil penelitian ini menujukan bahwa tepat pasien sebesar $100 \%$.

Tabel 5. Persentase (\%) Tepat Indikasi Obat Antibiotik Yang Digunakan

\begin{tabular}{ccc}
\hline Tepat Indikasi Obat & Jumlah Pasien & Persentase (\%) \\
\hline Tepat & 94 & 100 \\
Tidak Tepat & 0 & 0 \\
\hline Total & $\mathbf{9 4}$ & $\mathbf{1 0 0}$
\end{tabular}

Evaluasi ketepatan indikasi merupakan suatu proses penilaian terhadap pemilihan obat yang sesuai dengan yang dibutuhkan pasien. Ketepatan indikasi dalam pemilihan obat antibiotik didasarkan pada diagnosis yang ditegakkan seorang dokter dengan alasan medis. Evaluasi ketepatan indikasi dilihat dari perlu atau tidaknya pasien memperoleh antibiotik. ${ }^{12}$ Penggunaan obat antibiotik dikatakan tepat indikasi apa bila sesuai dengan tanda atau gejala dan diagnosis yang ada. Ketepatan pemilihan antibiotik sangat mempengaruhi keberhasilan terapi pada pasien Infeksi Saluran Pernafasan yang disebabkan infeksi bakteri. Selain itu ketepatan penggunaan antibiotik akan menghambat dan membunuh bakteri penyebab infeksi serta menentukan kualitas dari terapi yang 
dilakukan. Resistensi bakteri terhadap suatu antibiotik merupakan salah satu contoh ketidaktepatan penggunaan antibiotik baik dari pemilihan dan penentuan dosis penggunaan. ${ }^{13}$

Antibiotik diindikasikan untuk mencegah dan mengobati penyakit-penyakit infeksi. Pemberian pada kondisi yang bukan disebabkan oleh infeksi banyak ditemukan dalam praktik sehari-hari, baik dipusat kesehatan puskesmas, rumah sakit, maupun praktik swasta. Ketidak tepatan diagnosis pemilihan antibiotik, indikasi, dosis, cara pemberian, frekuensi, dan lama pemberian menjadi penyebab tidak akuratnya pengobatan infeksi dengan antibiotik. ${ }^{14}$

Berdasarkan hasil penelitian pada pasien yang terdiagnosis Infeksi Saluran Pernafasan di Puskesma Rawat Jalan Kecamatan Siulak Mukai Kabupaten Kerinci tahun 2018 didapatkan hasil $100 \%$ pasien tepat indikasi, menurut standar Pharmaceutical Care untuk penyakit Infeksi Saluran Pernafasan (2005) untuk pasien yang didiagnosis penyakit Infeksi Saluran Pernafasan seperti faringitis, bronkhitis, sinusitis, dan otitis media harus diberikan antibiotik karena pasien sudah dikatakan terinfeksi bakteri, maka pemberian antibiotik diindikasikan. ${ }^{10}$

Pada dasarnya perlu atau tidaknya pemberian antibiotik didasarkan pada hasil test mikrobiologis atau test kultur bakteri atau uji kepekaan kuman sehingga dapat diketahui dengan jenis bakteri apa yang menyebabkan infeksi. Namun dalam kenyataanya dilapangan, penentuan penggunaan antibiotik ini didasarkan pada kondisi pasien pada saat masuk perawatan. Pengujian laboratorium atau kultur bakteri jarang dilakukan karena membutuhkan waktu yang cukup lama untuk penangganan pasien, sehingga dalam penelitian ini analisis tepat indikasi obat didasarkan pada diagnosis oleh dokter yang menyatakan bahwa pasien infeksi saluran pernafasan, maka peneliti menggunakan pedoman Pharmaceutical Care untuk penyakit Infeksi Saluran Pernafasan sebagai pedoman apakah permberian antibiotik diindikasikan atau tidak terhadap diagnosis dokter.

Pengobatan faringitis antibiotik yang digunakan amoksisilin, berdasarkan pedoman Pharmaceutical Care (2005) amoksisilin merupakan antibiotik lini pertama untuk faringitis, menurut pedoman sudah tepat indikasi obat untuk faringitis. Untuk pengobatan sinusitis antibiotik yang digunakan kotrimoxazol, berdasarkan pedoman Pharmaceutical Care (2005) kotrimoxazol merupakan antibiotik lini pertama untuk sinusitis, menurut pedoman sudah tepat indikasi obat. Untuk pengobatan otitis media antibiotik yang digunakan cefixime, berdasarkan Pharmaceutical Care (2005) cefixime merupakan antibiotik lini kedua untuk pengobatan otitis media, menurut pedoman sudah tepat indikasi obat untuk otitis media. Untuk pengobatan bronkhitis antibiotik yang digunakan ciprofloksasin, berdasarkan Pharmaceutical Care (2005) ciprofloksasin merupakan antibiotik lini pertama untuk pengobatan bronkhitis, menurut pedoman sudah tepat indikasi obat untuk bronkhitis.

Tabel 6. Persentase (\%) Tepat Dosis Obat Antibiotik Yang Digunakan

\begin{tabular}{ccc}
\hline Tepat Dosis Obat & Jumlah Pasien & Persentase (\%) \\
\hline Tepat & 94 & 100 \\
Tidak Tepat & 0 & 0 \\
\hline Total & $\mathbf{9 4}$ & $\mathbf{1 0 0}$ \\
\hline
\end{tabular}


Tepat dosis didasarkan pada besaran dosis yang diberikan. dosis merupakan faktor yang penting dalam penentuan ketepatan pengobatan pasien jika dosis kurang penyembuhan tidak maksimal dan dosisi lebih akan menimbulkan toksisitas dan efeksamping yang tidak diinginkan pada terapi. $^{9}$ Penggunaan obat dosis berlebih maupun dosis kurang merupakan salah satu ciri yang mengindikasikan bahwa pengobatan yang diberikan tidak tepat sehingga dapat menyebabkan kegagalan terapi atau tidak tercapainya hasil terapi yang diinginkan. ${ }^{15}$

Pada penelitian yang dilakukan di Puskesmas Rawat Jalan Kecamatan Siulak Mukai Kabupaten Kerinci tahun 2018 didapatkan hasil untuk tepat dosis berdasarkan panduan yang digunakan yaitu Fharmaceutical Care untuk penyakit Infeksi Saluran Pernafasan dimana untuk tepat dosis sendiri sudah dikatakan tepat $100 \%$ karena pemberian dosis antibiotik sesuai dengan dosis dewasa pasien yang berusia $>25$ tahun. Menurut standar Pharmaceutical Care (2005) yang digunakan bahwa terapi antibiotik untuk faringitis pada pasien dewasa yaitu amoksisilin $3 \times 1$ sehari dengan dosis $500 \mathrm{mg}$, antibiotik kotrimoxazol pada pasien sinusitis $2 \times 1$ dengan dosis $960 \mathrm{mg}$, antibiotik ciprofloksasin pada pasien bronkhitis $2 \times 1$ sehari dengan dosis 500 $\mathrm{mg}$, dan antibiotik cefixime pasien otitis media $2 \times 1$ sehari dengan dosis dewasa $200 \mathrm{mg}^{10}$

Menurut Kementerian Kesehatan Republik Indonesia (2011), efektivitas terapi yang maksimal tidak akan tercapai apabila obat diberikan dengan dosis yang kurang. Pemberian dosis yang kurang juga dapat mengakibatkan resistensi bakteri yang tersisa. Sedangkan pemberian obat dengan dosis yang berlebihan dapat menimbulkan resiko efek samping dan toksisitas. ${ }^{16}$

Tabel 7. Kasus Interaksi Obat Antibiotik Dengan Obat Lain Yang Digunakan

\begin{tabular}{ccc}
\hline Interaksi Obat & Obat Lain & $\begin{array}{c}\text { Keparahan } \\
\text { Interaksi }\end{array}$ \\
\hline Amoksisilin $><$ & Paracetamol & - \\
Amoksisilin $><$ & Ctm & - \\
Amoksisilin $><$ & Ambroxol & - \\
Amoksisilin $><$ & Obh & - \\
Amoksisilin $><$ & Antasida & - \\
\hline Ciproflaksasin $><$ & Paracetamol & - \\
Ciproflaksasin $><$ & Ctm & - \\
Ciproflaksasin $><$ & Ambroxol & - \\
Ciproflaksasin $><$ & Obh & - \\
Ciproflaksasin $><$ & Antasida & - \\
Ciproflaksasin $><$ & Prenisolone & Major \\
Ciproflaksasin $><$ & Antasida & Moderat \\
\hline Cefixime $><$ & Paracetamol & - \\
Cefixime $><$ & Ctm & - \\
Cefixime $><$ & Ambroxol & - \\
Cefixime $><$ & Vit.B1 & - \\
Cefixime $><$ & Vit.B12 & - \\
\hline
\end{tabular}




\begin{tabular}{ccc}
\hline Interaksi Obat & Obat Lain & $\begin{array}{c}\text { Keparahan } \\
\text { Interaksi }\end{array}$ \\
\hline Kotrimoxazol $><$ & Paracetamol & - \\
Kotrimoxazol $><$ & Ctm & - \\
Kotrimoxazol $><$ & Ambroxol & - \\
Kotrimoxazol $><$ & Obh & - \\
Kotrimoxazol $><$ & Vit.B1 & - \\
Kotrimoxazol $><$ & Vit.B12 & - \\
\hline
\end{tabular}

Berdasarkan hasil penelitian ini Interaksi obat dilihat dengan menggunakan aplikasi Interaction chacker pada drug.com. Interaksi obat antibiotik jenis amoksisilin, kotrimoxazol, dan cefixime tidak terdapat interaksi obat dengan obat suportif yang di gunakan oleh pasien. Untuk jenis antibiotik ciprofloksasin terdapat interaksi obat yaitu dengan obat prednisolone memiliki tingkat keparahan interaksi major, dan interaksi obat antibiotik jenis ciprofloksasin dengan obat antasida (magnesium hidroxide) memiliki tingkat keparahan interaksi moderat. ${ }^{17}$

Tingkat keparahan interaksi obat dalam penelitian ini dimana terjadi pada antibiotik ciprofloksasin dengan obat prednisolone dengan tingkat keparahan major, dimana tingkat keparahan major sendiri efek fatal, dapat menyebabkan kematian. Antibiotik jenis ciprofloksasin dengan obat antasida dengan tingkat keparahan moderat, tingkat keparahan moderat sendiri efek sedang, dapat menyebabkan kerusakan organ. ${ }^{18}$

Ciprofloksasin dan obat-obatan lain dikelasnya dapat menyebabkan tendinitis dan tendon pecah, dan resikonya dapat meningkat ketika dikombinasikan dengan steroid seperti prednisolone. Orang dewasa yang berusia lebih dari 60 tahun dan mereka yang telah menerima transplantasi ginjal, jantung, dan atau paru-paru mungkin sangat rentan. Ruptur tendon dapat terjaidi selama atau sampai beberapa bulan setelah menyelesaikan pengobatan ciprofloksasin dan mungkin memerlukan pembedahan atau mengakibatkan kecacatan. Berhentilah meminum ciprofloksasin jika mengalami rasa skit, bengkak atau radang pada area tendon seperti bagian pergelangan kaki, bahu, bisep, tangan, atau ibu jari. Penting untuk deberitahu dokter tentang semua obat yang digunakan. ${ }^{17}$

Ciprofloksasin dan antasida (magnesium hydroxide) tidak boleh diminum secara bersamaan. Produk yang mengandung magnesium, aluminium, kalsium, besi, dan atau mineral lainnya dapat mengganggu penyerapan ciprofloksasin ke dalam aliran darah dan mengurangi efektivitasnya. Jika mungin, mungkin yang terbaik adalah menghindari mengkonsumsi magnesium hidroxide saat anda sedang dirawat dengan ciprofloksasin, jika tidak anda harus minum ciprofloksasin 2 sampai 4 jam sebelum atau 4 sampai 6 jam setelah dosis magnesium hidroxide. Penting untuk memberi tahu dokter tentang semua obat yang digunakan. ${ }^{17}$

\section{KESIMPULAN}

Pada penelitian ini dapat disimpulkan bahwa penggunaan obat antibiotik pada pasien Infeksi Saluran Pernafasan di Puskesmas Rawat Jalan Kecamatan Siulak Mukai Kabupaten Kerinci tahun 2018 sudah dikatakan tepat pengobatan $100 \%$, Serta adanya kejadian interaksi obat sebanyak 2 kejadian.

\section{DAFTAR PUSTAKA}

1. Sukana B, Bisara D. Kejadian ISPA dan Pneumonia Akibat Kebakaran Hutan Di 
Kabupaten Pulang Pisau Provinsi Kalimantan Tengah. Jurnal Ekologi Kesehatan. 2015;14(3):250-258.

2. Yuniva R. Hubungan Curah Hujan Dan Titik Panas (Hotspot) Sebagai Indikator Terjadinya Kebakaran Hutan Dan Lahan Di Provinsi Jambi (Skripsi). Bogor. Institut Pertanian Bogor, 2015.

3. Riset Kesehatan Dasar (Riskesdas). Badan Penelitian dan Pengembangan Kesehatan Kementerian Rl tahun 2018. Jakarta. Kementrian Kesehatan RI, 2018.

4. Dinas Kesehatan Kabupaten Kerinci. 10 Penyakit Terbesar di Kabupaten Kerinci Tahun 2018. 2018.

5. WHO. Pencegahan dan Pengendalian Infeksi Saluran Pernapasan Akut (ISPA) Yang Cenderung Menjadi Epidemi dan Pademi di Fasilitas Pelayanan Kesehatan. Jakarta. Pedoman Interim WHO, 2007.

6. Depkes RI. Klasifikasi Umur Menurut Kategori. Jakarta: Ditjen Yankes, 2009.

7. Anorital. Morbiditas dan Multi Morbiditas Pada Kelompok Lanjut Usia di Indonesia. Jurnal Biotek Medisiana Indonesia. 2015;4 (2):77-88.

8. Harahap HY. Evaluasi Penggunaan Antibiotik Pada Pasien Infeksi Saluran Pernafasan Akut di Instalasi Rawat Jalan Rumah Sakit Umum Pusat H. Adam Malik Medan (Skripsi). Medan. Universitas Sumatera Utara, 2017.

9. Syahila. Analisis Penggunaan Antibiotik Pada Infeksi Saluran Pernafasan Atas Rawat Inap Di RSUD DR. Moewardi Pada Tahun 2016 (Skripsi). Surakarta. Fakultas Farmasi Universitas Setia Budi Surakarta, 2018.

10. Pharmaceutical Care. Pharmaceutical Care Untuk Penyakit Infeksi Saluran Pernafasan. Jakarta. Direktorat Bina Farmasi Komunitas dan Klinik Direktorat Jenderal Bina Kefarmasian Dan Alat
Kesehatan Departemen Kesehatan RI, 2005.

11. Anisa DN. Evaluasi Penggunaan Antibiotik Pada Penyakit Infeksi Saluran Pernafasan Atas (ISPa) Anak di Instalasi Rawat Jalan RSUD Y Tahun 2015 (Skripsi). Surakarta. Fakultas Farmasi Universitas Muhammadiyah Surakarta, 2017.

12. Grassella, Yuswar MA, Purwanti NU. Studi Rasionalitas Penggunaan Antibiotik dan Interaksi Obat Pada Pasien Anak Terdiagnosis Infeksi Saluran Pernafasan Akut (ISPA) Di Instalasi Rawat Jalan RSUD Sultan Syarif Mohamad Alkadrie Pontianak Tahun 2018. Jurnal Mahasiswa Farmasi Fakultas Kedokteran UNTAN. 2019;4(1):117.

13. Sadewa SG. Evaluasi Penggunaan Antibiotik Pada Pasien Infeksi Saluran Pernafasan Atas Akut (ISPAa) di Instalasi Rawat Inap RSUD Unggaran Kabupaten Semarang Tahun 2016 (Skripsi). Surakarta. Fakultas Farmasi Universitas Muhammadiyah Surakarta, 2017.

14. Kliegman R, Stanton B and Behrman R. Nelson Textbook of Pediatrics. 19 ed. Diedit oleh J. St. Geme dan N. Schor. United States: Saunders., 2011.

15. BPOM RI. Badan Pengawasan Obat Dan Makanan. Jakarta, 2014

16. Kemenkes RI. Peraturan Menteri Kesehatan Nomor 2406/Menkes/Per/XII/2011 tentang Pedoman Umum Penggunaan Antibiotik. Jakarta: Kementerian Kesehatan RI. 2011.

17. Drugs.com. (2020). Prescription Drug Information, Interactions \& Side Effects. http://www.drugs.com/drug_interactions.ht $\mathrm{ml}$

18. Tarto D. Drug Interaction Facts, 6th Edition. 175, 348, 376, 391, 399, 778, 962, 971, 972, Facts \& Comparison A Wolters Kluwers Company. 2016. 